\title{
Management of current assets in the context of increasing the Enterprise's Profitability
}

\author{
Iluta Arbidane \\ Rezeknes Augstskola, Faculty of Economics and management. \\ Address: Atbrivosanas aleja 115, Rezekne, LV-4601, Latvia.
}

\begin{abstract}
In order to ensure the financial sustainability of companies under current economic conditions successful management of current assets is crucial. In practice it is quite often observed that the decisions related to current assets management in Latvian companies are made in the short-term aspects without making analysis. Efficient management of working capital is an essential condition of rise in profitability of a company. Potentialities of working capital management in the context of efficient running of business have not been studied in Latvia up until now. The main aim of this article is to examine the effect of working capital on profitability of Latvian companies. The results of the research that has been performed in relation to Latvian enterprises confirm the existence of a correlation between components of working capital and profitability. The developed regression equations meant for forecasting profitability of a company applying working capital management methods can be used by Latvian enterprises. It follows that managers of an enterprise can forecast indexes characterizing profit, managing components of working capital and maintaining it on the optimum level
\end{abstract}

Keywords: current assets, current assets management, profitability.

\section{INTRODUCTION}

Sustainable development of the economic subjects in the economic space largely depends on the ability of efficient management of their financial resources; on a basis of the scientific findings of the theory of economics and management it is focused on three basic directions: capital investments, capital structure and management of the working capital. Investments of financial resources into current assets is creation of the future capital value in long-term, which is important for company's shareholders; the management of current assets, which is directed to ensuring the company's solvency within the entire operating cycle, in is turn, is essential for the company's profitability and ability to discharge its liabilities, which is a precondition for general sustainable development of the enterprise.

The economic category - current assets - is interpreted within the framework of the management of finances in scientific and practical research. The author believes that functions of the current assets in entrepreneurship and their significance in economic growth of the national economy are not less important.

On the macro level, the current assets are elements of economic growth, their definite quantity and quality may influence changes in demand and supply within a definite geographical area. From the point of view of entrepreneurship, current assets is an important precondition for company's development and value creation. From 2008 to 2013, the specific gravity of the current assets in enterprises' total assets made $42.3 \%-36.95 \%$.

The topicality of the research is defined by the fact that in the modern conditions of growing competition the management of current assets has become an important function of the enterprise management influencing results of the economic activity. The large number of elements of current assets in their material and financial composition requires the individual and dynamic management's approach in the decision making process. The important component of management of the enterprise's current assets is increasing of the profitability of the economic activity. Significant changes in macroeconomics create the necessity for the management to take strategic decisions in management of current assets to achieve the main target of entrepreneurs - to get profit.

\section{LITERATURE REVIEW}

Historically the relationship of current assets management and corporate profitability has been studied by various authors for example, Shin and Soenen [18] (1998); Deloof [3] 2003; Lazaridis and Tryfonidis [9] (2006), Padachi [13] (2006), GarciaTereul and Martinez-Solano [6] (2007); Raheman and Nasr [16] (2007); Mathuva [10] (2009); Dong and Su 
[4] (2010); Sharma and Kumar [17] (2011) and others. Studies focused on the relationship between working capital and profitability in different respects (Table 1).

Successful management of current assets of a company plays an essential role in ensuring financial sustainability of an enterprise under current economic conditions. Current assets and potentialities of their management in the context of business activity practically have not been studied in Latvia up. In their turn, such studies are widely represented in Russia, EU, America and other countries.

During her research the author summarised various scientists' studies related to the interrelations between management of current assets and profitability.

TABLE 1

Results of research of correlation of profit/profitability with turnover indicators

\begin{tabular}{|c|c|c|c|c|c|}
\hline Author & $\begin{array}{l}\text { Indicator of } \\
\text { profit/ } \\
\text { profitability }\end{array}$ & $\begin{array}{c}\text { Correlation of } \\
\text { receivables } \\
\text { collection } \\
\text { period(RCP) with } \\
\text { profitability }\end{array}$ & $\begin{array}{l}\text { Correlation of } \\
\text { inventory } \\
\text { conversion } \\
\text { period(ICP) with } \\
\text { profitability }\end{array}$ & $\begin{array}{l}\text { Correlation of } \\
\text { payables' deferral } \\
\text { period(PDP) with } \\
\text { profitability }\end{array}$ & $\begin{array}{c}\text { Correlation of } \\
\text { cash conversion } \\
\text { cycle }(C C C) \text { with } \\
\text { profitability }\end{array}$ \\
\hline Deloof (2003) [3] & GOP & Negative & Negative & Negative & Negative \\
\hline Karaduman (2004) [8] & ROA & Negative & Negative & Negative & Negative \\
\hline $\begin{array}{l}\text { Lazaridis, Tryfonidis } \\
(2006)[2]\end{array}$ & Gross Profit & Negative & Negative & Negative & Negative \\
\hline Padachi (2006) [13] & $\mathrm{ROA}$ & Negative & $\begin{array}{l}\text { No significant } \\
\text { relationship }\end{array}$ & Negative & Negative \\
\hline $\begin{array}{l}\text { Garcia-Tereul, Solano } \\
(2007)[6]\end{array}$ & ROA & Negative & Negative & $\begin{array}{l}\text { No significant } \\
\text { relationship }\end{array}$ & Negative \\
\hline $\begin{array}{l}\text { Raheman, Nasr (2007) } \\
{[2]}\end{array}$ & ROA & Negative & Negative & Negative & Negative \\
\hline Mathuva (2009) [10] & ROS & Negative & Positive & Positive & Negative \\
\hline Nobanee, (2009) [12] & GOP & Negative & Negative & Positive & Negative \\
\hline Enqvist (2009) [5] & ROA, GOP & Negative & $\begin{array}{l}\text { No significant } \\
\text { relationship }\end{array}$ & Negative & Negative \\
\hline Gill (2010) [7] & Gross Profit & Negative & $\begin{array}{l}\text { No significant } \\
\text { relationship }\end{array}$ & $\begin{array}{l}\text { No significant } \\
\text { relationship }\end{array}$ & Positive \\
\hline Dong, Su (2010) [4] & GOP & $\begin{array}{l}\text { No significant } \\
\text { relationship }\end{array}$ & Negative & Negative & Negative \\
\hline $\begin{array}{l}\text { Sharma, Kumar } \\
(2011) \text { [17] }\end{array}$ & $\mathrm{ROA}$ & Positive & Negative & Negative & $\begin{array}{l}\text { Positive (not } \\
\text { significant) }\end{array}$ \\
\hline
\end{tabular}

* Gross Operating Income - GOP; Return on

Assets - ROA; Net Operating Profit - ROS Source: author's summarised information

In their research, authors used various profitability indicators or also gross profit, which is substantiated with the research aim and reflects the connection with the turnover of elements of working capital.

Return on Assets (ROA) is one of the most important indicators of the enterprise's activity. These indicators give possibility to judge how efficiently the company uses its assets to get profit. Gross Operating Income (GOP) shows the enterprise's ability to get profit from the basic activity, i.e. from performing enterprise's economic operations. Gross Operating Income excludes incomes derived from selling assets or other enterprises' ownership. As enterprise's current assets are only a part of assets that is used every day in the company's working process, the author believes that this indicator reflects the 
connection with the indicators of the turnover of working capital elements in the best way.

\section{THE METHODOLOGIE AND MODEL}

The author used the method of survey in her thesis. The data that she received showed quite unvaried results and do not express significant difference in opinions, attitudes and assessments amongst entrepreneurs. Stability of the results in relation to application of various analysis tools points to tendencies of current asset management at enterprises in Latvia.

The research can be conventionally divided into two parts; in the first part, the author brings forward six conditions and several explaining criteria of factors influencing current asset management and characterising indicators of current asset types. In the second part, there are 10 statements about actual aspects of management of current assets at a concrete enterprise, as well as the author asks to name annual account indicators characterising the enterprise's activity.

The data were obtained after summarising enterprises' managers' assessment. 226 questionnaires were received. When doing primary processing of the questionnaires, the author selected 194 questionnaires ( $85.83 \%$ of the total number of the questionnaires) according to the company's sphere, dividing respondents into spheres:

- production sphere NACE codes: A, B, C, D (further in the text -1 ) -66 respondents $(29.2 \%)$

- trade sector NACE codes: G, J (further in the text -2$)-70$ respondents $(30.97 \%)$;

- service sector NACE codes: E, H, I, K, M, N, $\mathrm{O}$ (further in the text -3 ) -58 respondents $(25.66 \%)$.

The estimates of average indicators reflect similar evaluation both in the entire selection and in separate sectors. Average assessments indicate similar evaluation to define tendencies, then counted aggregated factors according to condition groups are standardised according to the average, which is 0 , but the mean squared deviation is 1 . After standardisation the average indicators get 0 .

When comparing the enterprises' assessments of current asset management using Kruskal Wallis test, the author came to the conclusion that there are differences between sectors. Assessments in the trade sphere are lower than the average, but assessments in the production and services spheres are above the average. The statistical significance by the spheres is observed in relation to actual aspects of current asset management at the enterprise (AA) (Kruskal Wallis Test, $p<0.082)$. The author concludes that at enterprises working in the sphere of services, management of current assets is not paid much attention to, and on the contrary, the evaluation done by production and trade companies reflects application of methods of current asset management.

For doing the research the author used data that she had acquired with help of the survey conducted among management of concrete enterprises. The choice of variables was stipulated by the research that had been done in the theoretical part, empirical studies and taking Deloof's [3] (2003), Raheman, Nasr's [15] (2007) studies as a basis, as well as taking into account available data. In Table 2 , all variables that were used in the research are summarised; their abbreviations and estimate formulae are given in the same table.

TABLE 2.

Formulae of variables and abbreviations

\begin{tabular}{|l|l|l|}
\hline Variable & Abbreviation & Formula \\
\hline The dependent variable & \\
\hline $\begin{array}{l}\text { Gross Operating } \\
\text { Profitability }\end{array}$ & GOP & $\begin{array}{l}\text { (Sales - Cost of } \\
\text { Goods Sold) / (Total } \\
\text { Assets - Financial } \\
\text { Assets) }\end{array}$ \\
\hline Return on Assets & ROA & $\begin{array}{l}\text { Neto income / Total } \\
\text { assets }\end{array}$ \\
\hline
\end{tabular}

The Explanatory variables

\begin{tabular}{|l|l|l|}
\hline $\begin{array}{l}\text { Receivables } \\
\text { Collection } \\
\text { Period }\end{array}$ & RCP & $\begin{array}{l}\text { Accounts receivable } \\
\text { / Sales)*365 }\end{array}$ \\
\hline $\begin{array}{l}\text { Inventory } \\
\text { Conversion Period }\end{array}$ & ICP & $\begin{array}{l}\text { (Inventories / Cost of } \\
\text { Goods sold)*365 }\end{array}$ \\
\hline $\begin{array}{l}\text { Payables Deferral } \\
\text { Period }\end{array}$ & PDP & $\begin{array}{l}\text { (Accounts payable / } \\
\text { Cost of Goods } \\
\text { sold)*365 }\end{array}$ \\
\hline $\begin{array}{l}\text { Cash Conversion } \\
\text { Cycle }\end{array}$ & CCC & RCP + ICP - PDP \\
\hline
\end{tabular}

The control variables

\begin{tabular}{|l|l|l|}
\hline Size of Companies & LnS & $\begin{array}{l}\text { Natural Logarithm of } \\
\text { Sales }\end{array}$ \\
\hline Debt Ratio & DR & $\begin{array}{l}\text { Total Debt / Total } \\
\text { Assets }\end{array}$ \\
\hline Current Ratio & CR & $\begin{array}{l}\text { Current assets / } \\
\text { Current liabilities }\end{array}$ \\
\hline $\begin{array}{l}\text { Working capital in } \\
\text { relation to turnover }\end{array}$ & WCS & $\begin{array}{l}\text { Current assets - } \\
\text { Current liabilities / } \\
\text { Sales \% }\end{array}$ \\
\hline
\end{tabular}

Source: author's summarised information

\section{RESULTS AND DISCUSSION}

\section{Correlation analysis of selected enterprises' indicators.}

The correlation analysis describes relations between the dependent variable, explanatory and control variables. The analysis has been done using Pearson's correlation analysis. In research related to interconnections between working capital and 
profitability, Pearson's correlation analysis was used by several researchers: Deloof [3] (2003), Padachi [14] (2006), Mathuva [10] (2009), Gill, Biger, Mathur [7] (2010), Enqvist, Graham, Nikkinen [5] (2010).
Pearson's correlation analysis shows the relation between variables, but does not indicate its reasons (Shin, Soenen [18] (1998); Deloof [3], (2003), Mathuva [10] (2009), Dong, Su [4] (2010)).

TABLE 3.

Results of Pearson's correlation of enterprises' variables, n=194 enterprises of Latvia, 2013

\begin{tabular}{|c|c|c|c|c|c|c|c|c|c|}
\hline & GOP & $\mathrm{RCP}$ & ICP & PDP & $\mathrm{CCC}$ & LnS & DR & CR & WCS \\
\hline GOP & 1 & & & & & & & & \\
\hline $\mathrm{RCP}$ & $.235^{*}$ & 1 & & & & & & & \\
\hline$\overline{\mathrm{ICP}}$ & $.348^{*}$ & -.133 & 1 & & & & & & \\
\hline PDP & $.507 * *$ & -.034 & $.768 * *$ & 1 & & & & & \\
\hline $\mathrm{CCC}$ & $-.354 * *$ & .046 & .046 & $-.600^{* *}$ & 1 & & & & \\
\hline LnS & $.330^{* *}$ & -.151 & $.267 * *$ & $.239^{*}$ & $\begin{array}{l}-057 \\
\end{array}$ & 1 & & & \\
\hline$\overline{D R}$ & $-.476 * *$ & -.032 & -.041 & .017 & $\begin{array}{l}.092 \\
\end{array}$ & $-.286 * *$ & 1 & & \\
\hline $\mathrm{CR}$ & .072 & -.047 & -.032 & -.066 & .060 & .044 & -.189 & 1 & \\
\hline WCS & $.222 *$ & $.325 * *$ & $.241^{*}$ & -.124 & $.502 * *$ & .089 & $-.351 * *$ & .082 & 1 \\
\hline
\end{tabular}

*significant at 0.05 level

** significant at 0.01 level

Source: author's data calculations from SPSS software

*** GOP - Gross Operating Profitability, RCP - Receivables Collection Period, ICP - Inventory Conversion Period, PDP Payables Deferral Period, CCC - Cash Conversion Cycle, LNS Natural Logarithm of Sales, DR - Debt Ratio, CR - Current Ratio, WSC -relation of working capital to turnover.

Pearson's correlation ratio in relation to all variables (Table 3). In the selected enterprises there is correlation between almost all the variables, with the exception of total liquidity and gross operating profitability. Analysing the correlation between GOP and explanatory variables, it is seen that there is significant positive correlation with the payables deferral period $(r=0.507)$. Though some researchers proved negative correlation between GOP and PDP in their works, in some studies (Mathuva [10], Nobanee [12]) there is also positive correlation between these indicators. The author concludes that the positive correlation indicates that enterprises are realising the creditors' debt paying policy, which is directed to slow payments. It is also proved by results of the primary data analysis. Such a creditor management policy gives opportunity to use available cash assets longer and increases profitability.

There is significant negative correlation between GOP and CCC $(r=-0.354)$. Research in this sphere certifies that this correlation is usually negative. It shows that the enterprises' cash policy is directed to shortening of the cash conversion cycle.

Positive correlation is observed between GOP and RCP $(r=0.235)$. The largest part of studies prove that this correlation is negative. It means that it is possible to improve profitability by managing receivables collection period. Positive GOP and RCP correlation was proved in Sharma, Kumar's [17] (2011) works about enterprises in India.

There is positive correlation between GOP and ICP $(r=0.348)$. Like in the case above, the largest part of studies prove negative or insignificant correlation. Positive correlation was noted by Mathuva [10] (2009) at enterprises in Japan, and he concluded that excessive concentration on reduction of inventory cannot be evaluated positively. The author of the thesis draws a conclusion that the excessive concentration on reduction of inventory and the conversion period can give an opposite effect, i.e. decrease of profitability. Maintaining of the inventory level can decrease delivery costs, prevent from price variation, ensures continuity of the production process. Sufficiently high level of finished commodity and goods positively influences the enterprise's ability to keep customers and the profit without decreasing the production amount.

Analysing controlling variables, it was discovered that there is significant correlation between the size of the enterprise and profitability $(r=0.330)$. This connection proves that the size of the enterprise influences its profitability. Growth of the enterprise and increase of the turnover are one of the most important entrepreneurs' aims, which is also proved by the correlation analysis.

Negative correlation between DR and GOP ( $\mathrm{r}=$ 0.476) characterises the influence of the external financial risk on possibilities of profitability increase. In various authors' studies, negative correlation between CR and GOP was discovered, but it has not been found in the given selected group.

\section{Regression Analysis}

The regression analysis is used to investigate possibilities of gross operating profitability 
forecasting using methods of management of current assets. In order to perform this analysis the Fixed effects model (FEM) was applied. FEM explains possibilities of profitability forecast at enterprises. The choice of this model is useful, when a concrete group Nof enterprises is investigated - it is random and impossible to influence. FEM method was used in other researchers' works Deloof [3] (2003), Padachi [13] (2006), Mathuva [10] (2009), Dong, Su [4] 2010).

For expressing gross operating profitability (GOP) they use multiple factor correlation - regression equation in the linear form, where the dependent variable is GOP, as well as explanatory variables, that can influence GOP.

The formula for calculation of GOP is developed as equations of multiple linear regression, where GOP is used as the dependent variable, but the following groups of factors are used as the independent variables:

- $\quad R C P, \operatorname{Ln} S, D R, C R$;

- ICP, LnS, DR, CR;

- PDP, LnS, DR, CR;

- CCC, LnS, DR, CR.

An impact of working capital management upon corporate profitability was modelled using the following regression equations:

$\mathrm{GOP}=\mathrm{f}(\mathrm{RCP}, \mathrm{ICP}, \mathrm{PDP}, \mathrm{CCC}, \mathrm{LnS}, \mathrm{CR}, \mathrm{DR}, \lambda)(1)$

$\mathrm{GOP}=\beta 0+\beta 1(\mathrm{RCPit})+\beta 2(\mathrm{CRit})+\beta 3(\mathrm{DRit})+$

$+\beta 4($ LnSit $)+\varepsilon$

$\mathrm{GOP}=\beta 0+\beta 1(\mathrm{ICPit})+\beta 2(\mathrm{CRit})+\beta 3(\mathrm{DRit})+$

$+\beta 4($ LnSit $)+\varepsilon$

$\mathrm{GOP}=\beta 0+\beta 1(\mathrm{PDPit})+\beta 2(\mathrm{CRit})+\beta 3(\mathrm{DR} i \mathrm{t})+$

$+\beta 4($ LnSit $)+\varepsilon$

$\mathrm{GOP}=\beta 0+\beta 1($ CCCit $)+\beta 2($ CRit $)+\beta 3($ DRit $)++\beta 4($ LnSit $)$

$+\varepsilon$

TABLE 4.

Determination coefficients for gross profitability forecasting according to various explanatory variables

\begin{tabular}{|l|c|l|l|}
\hline \multicolumn{4}{|c|}{ according to various explanatory variables } \\
\hline $\begin{array}{l}\text { Determination } \\
\text { coefficient }\end{array}$ & $\begin{array}{l}\text { Determination } \\
\text { error }\end{array}$ & $\begin{array}{l}\text { Standardised } \\
\text { coefficient } \\
\text { Beta }\end{array}$ \\
\hline Constant & -15.038 & 20.551 & 0.257 \\
RCP & 0.117 & 0.404 & -0.398 \\
DR & -25.769 & 5.818 & 0.251 \\
LnS & 4.023 & 1.460 & \\
\hline
\end{tabular}

\begin{tabular}{|l|r|l|l|}
\hline Constant & 35.408 & 4.906 & \\
PDP & 0.033 & 0.005 & 0.514 \\
DR & -32.284 & 4.449 & -0.524 \\
\hline Constant & 38.388 & 5.690 & \\
ICP & 0.026 & 5.149 & -0.502 \\
DR & -30.944 & 0.007 & 0.325 \\
\hline Constant & 3.267 & 16.964 & \\
CCC & -0.039 & 0.008 & -0.388 \\
DR & -30.288 & 4.998 & -0.492 \\
\hline
\end{tabular}

\begin{tabular}{|c|c|c|c|}
\hline LnS & 3.197 & 1.239 & 0.209 \\
\hline Constant & -15.038 & 20.551 & \\
\hline $\mathrm{RCP}$ & 0.117 & 0.404 & 0.257 \\
\hline DR & -25.769 & 5.818 & -0.398 \\
\hline $\mathrm{LnS}$ & 4.023 & 1.460 & 0.251 \\
\hline Constant & 35.408 & 4.906 & \\
\hline PDP & 0.033 & 0.005 & 0.514 \\
\hline DR & -32.284 & 4.449 & -0.524 \\
\hline Constant & 38.388 & 5.690 & \\
\hline ICP & 0.026 & 5.149 & -0.502 \\
\hline DR & -30.944 & 0.007 & 0.325 \\
\hline Constant & 3.267 & 16.964 & \\
\hline $\mathrm{CCC}$ & -0.039 & 0.008 & -0.388 \\
\hline DR & -30.288 & 4.998 & -0.492 \\
\hline LnS & 3.197 & 1.239 & 0.209 \\
\hline Constant & -15.038 & 20.551 & \\
\hline $\mathrm{RCP}$ & 0.117 & 0.404 & 0.257 \\
\hline DR & -25.769 & 5.818 & -0.398 \\
\hline LnS & 4.023 & 1.460 & 0.251 \\
\hline Constant & 35.408 & 4.906 & \\
\hline PDP & 0.033 & 0.005 & 0.514 \\
\hline DR & -32.284 & 4.449 & -0.524 \\
\hline Constant & 38.388 & 5.690 & \\
\hline $\mathrm{ICP}$ & 0.026 & 5.149 & -0.502 \\
\hline DR & -30.944 & 0.007 & 0.325 \\
\hline Constant & 3.267 & 16.964 & \\
\hline $\mathrm{CCC}$ & -0.039 & 0.008 & -0.388 \\
\hline DR & -30.288 & 4.998 & -0.492 \\
\hline $\mathrm{LnS}$ & 3.197 & 1.239 & 0.209 \\
\hline Constant & -15.038 & 20.551 & \\
\hline $\mathrm{RCP}$ & 0.117 & 0.404 & 0.257 \\
\hline DR & -25.769 & 5.818 & -0.398 \\
\hline LnS & 4.023 & 1.460 & 0.251 \\
\hline Constant & 35.408 & 4.906 & \\
\hline PDP & 0.033 & 0.005 & 0.514 \\
\hline DR & -32.284 & 4.449 & -0.524 \\
\hline
\end{tabular}

Source: author's data calculations from SPSS software

* GOP - Gross Operating Profitability, RCP - Receivables Collection Period, ICP - Inventory Conversion Period, PDP Payables Deferral Period, CCC - Cash Conversion Cycle, LNS Natural Logarithm of Sales, DR - Debt Ratio.

Regression equations are solved for the entire selected group. In Table 4, determination coefficients for various explanatory variables are summarised.

As a result of the analysis, four regression equations were made, which are expressed with every explanatory variable. 
TABLE 5 .

Regression models of gross profitability forecasting according to various explanatory variables

\begin{tabular}{|l|c|c|}
\hline \multicolumn{1}{|c|}{ Regression equation } & $\mathrm{R}$ & $\mathrm{R}^{2}$ \\
\hline $\begin{array}{l}\mathrm{GOP}=-15.038+0.117 * \mathrm{RCP} \\
25.769 * \mathrm{DR}+4.023 \mathrm{LnS}\end{array}$ & 0.576 & 0.331 \\
\hline $\begin{array}{l}\mathrm{GOP}=35.408+0.033 * \mathrm{PDP} \\
32.284 * \mathrm{DR}\end{array}$ & 0.728 & 0.530 \\
\hline $\begin{array}{l}\mathrm{GOP}=38.388+0.026 * \mathrm{ICP} \\
\text { 30.944*DR }\end{array}$ & 0.610 & 0,372 \\
\hline $\begin{array}{l}\mathrm{GOP}=3.267-0.039 * \mathrm{CCC}-30.288 * \mathrm{DR} \\
+3.197 * \mathrm{LnS}\end{array}$ & 0.685 & 0.469 \\
\hline
\end{tabular}

Source: author's data calculations from SPSS software

* GOP - Gross Operating Profitability, RCP - Receivables Collection Period, ICP - Inventory Conversion Period, PDP Payables Deferral Period, CCC - Cash Conversion Cycle, LNS Natural Logarithm of Sales, DR - Debt Ratio.

Regression models were made using the Fisher Ftest. F-test is applied, when statistical models are compared for a set of data to define a model which better suits for usage. As a result of the F-test the acquired models fit the data using a smaller square. In Table 5, GOP variance is expressed with:

- $\mathrm{RCP}$ for 33\%, which is related to $\mathrm{DR}$ and $\mathrm{LnS}$;

- PDP $-53 \%$, related to DR;

- $\mathrm{ICP}-37 \%$ related to DR;

- $\mathrm{CCC}-47 \%$, related to DR and $\mathrm{LnS}$.

In general, we may conclude that all regression coefficients are important. Developed regression equations can be used for gross profit cost-efficiency forecasting and decision-making in relation to management of current assets, or while implementing management of current assets, it is possible to forecast gross operating profitability.

In order to make more exact regression models, as well as to guarantee better forecasting significance, the author conducted the regression analysis by spheres. During the analysis the author concluded that in none of the spheres there is a significant relation between GOP and RCP.

In Table 6, determination coefficients are shown for variances for enterprises working in the production sphere. For the production sphere determination coefficients were found for variances PDP, ICP and CCC.

For the production sector, the regression models were made expressing GOP with:

- $\mathrm{PDP}-82 \%$, related to DR;

- ICP $-69 \%$, related to DR and LnS;

- $\mathrm{CCC}-84 \%$, related to DR.

On basis of the data in Table 7, it is possible to conclude that the acquired regression coefficients are significant with credibility limit $70 \%$ and more. Regression equations can be used at production companies for gross profit cost-efficiency forecasting using possibilities of current asset management.
TABLE 6.

Regression models for gross profitability forecasting according to various explanatory variables in the production sphere

\begin{tabular}{|l|r|r|r|}
\hline Model & $\begin{array}{c}\text { Determination } \\
\text { coefficient }\end{array}$ & $\begin{array}{c}\text { Determination } \\
\text { error }\end{array}$ & $\begin{array}{c}\text { Standardised } \\
\text { coefficient } \\
\text { Beta }\end{array}$ \\
\hline Constant & 47.083 & 5.851 & \\
PDP & 0.033 & 0.004 & 0.581 \\
DR & -49.050 & 5.547 & -0.695 \\
\hline Constant & 62.081 & 9.431 & \\
ICP & 0.043 & 0.011 & 0.396 \\
DR & -54.917 & 8.076 & -0.778 \\
LnS & -0.374 & 0.147 & -0.291 \\
\hline Constant & 57.215 & 5.324 & \\
CCC & -0.51 & 0.006 & -0.597 \\
DR & -52.829 & 5.317 & -0.748 \\
\hline
\end{tabular}

Determination coefficients for forecasting gross profitability according to various explanatory variables in the production sphere

Source: author's data calculations from SPSS software

* GOP - Gross Operating Profitability, ICP - Inventory Conversion Period, PDP - Payables Deferral Period, CCC - Cash Conversion Cycle, LNS - Natural Logarithm of Sales, DR - Debt Ratio.

TABLE 7.

Regression models for gross profitability forecasting according to various explanatory variables in the production sphere

\begin{tabular}{|l|c|c|}
\hline \multicolumn{1}{|c|}{ Regression equation } & $\mathrm{R}$ & $\mathrm{R}^{2}$ \\
\hline $\begin{array}{l}\mathrm{GOP}=47.083+0.033 * \mathrm{PDP}- \\
49.050 * \mathrm{DR}\end{array}$ & 0.906 & 0.82 \\
\hline $\mathrm{GOP}=62.081+0.043 * \mathrm{ICP}-$ & 0.832 & 0.69 \\
$54.917 * \mathrm{DR}-0.374 \mathrm{Lns}$ & & \\
\hline $\begin{array}{l}\mathrm{GOP}=57.215-0.51 * \mathrm{CCC}- \\
52.829 * \mathrm{DR}\end{array}$ & 0.915 & 0.83 \\
\hline
\end{tabular}

Source: author's data calculations from SPSS software

* GOP - Gross Operating Profitability, ICP - Inventory Conversion Period, PDP - Payables Deferral Period, CCC - Cash Conversion Cycle, LNS - Natural Logarithm of Sales, DR - Debt Ratio.

TABLE 8.

Determination coefficients for forecasting gross profitability according to various variables in the trade sector

\begin{tabular}{|l|r|r|r|}
\hline Model & $\begin{array}{c}\text { Determination } \\
\text { coefficient }\end{array}$ & $\begin{array}{c}\text { Determination } \\
\text { error }\end{array}$ & $\begin{array}{c}\text { Standardised } \\
\text { coefficient } \\
\text { Beta }\end{array}$ \\
\hline Constant & -20.341 & 11.269 & \\
PDP & 0.027 & 0.004 & 0.688 \\
LnS & 2.253 & 0.940 & 0.260 \\
\hline Constant & -18.793 & 12.476 & \\
ICP & 0.021 & 0.004 & 0.688 \\
CR & -0.102 & 0.046 & -0.253 \\
LnS & 2.331 & 1.007 & 0.269 \\
\hline
\end{tabular}

Source: author's data calculations from SPSS software

* GOP - Gross Operating Profitability, ICP - Inventory Conversion Period, PDP - Payables Deferral Period, LNS - Natural Logarithm of Sales, CR - Current Ratio. 
In the selected group of the trade sector determination coefficients were acquired only in relation to PDP and ICP (Table 8). No connection was found between other explanatory variables and GOP.

TABLE 9.

Regression models for gross profitability forecasting according to various explanatory variables in the trade sphere

\begin{tabular}{|l|c|c|}
\hline \multicolumn{1}{|c|}{ Regression equation } & $\mathrm{R}$ & $\mathrm{R}^{2}$ \\
\hline $\mathrm{GOP}=-20.341+0.027 * \mathrm{PDP}+$ & 0.825 & 0.680 \\
$2.253 * \mathrm{LnS}$ & & \\
\hline $\begin{array}{l}\mathrm{GOP}=-18.793+0.021 * \mathrm{ICP}- \\
0.102 * \mathrm{CR}+2.331 \mathrm{Lns}\end{array}$ & 0.810 & 0.656 \\
\hline
\end{tabular}

Source: author's data calculations from SPSS software

* GOP - Gross Operating Profitability, ICP - Inventory Conversion Period, PDP - Payables Deferral Period, LNS - Natural Logarithm of Sales, CR - Current Ratio.

In the trade sphere, the regression models were developed with (Table 9):

- GOP, expressing it with PDP of $68 \%$, related to $\mathrm{LnS}$;

- $\mathrm{ICP}-66 \%$ related to $\mathrm{CR}$ and $\mathrm{LnS}$.

The credibility of the regression equations is high $-70 \%$. It allows us to conclude that the equations can be used at trade companies for GOP forecasting using methods of inventory and payables management.

TABLE 10.

Determination coefficients for gross profitability forecasting according to various explanatory variables in the sphere of services

\begin{tabular}{|l|r|r|r|}
\hline Model & $\begin{array}{r}\text { Determinati } \\
\text { on } \\
\text { coefficient }\end{array}$ & $\begin{array}{c}\text { Determination } \\
\text { error }\end{array}$ & $\begin{array}{c}\text { Standardised } \\
\text { coefficient } \\
\text { Beta }\end{array}$ \\
\hline Constant & -122.588 & 41.429 & \\
CCC & -0.188 & 0.039 & 0.396 \\
DR & -39.680 & 8.133 & -0.696 \\
LnS & 15.579 & 3.931 & 0.530 \\
\hline
\end{tabular}

Source: author's data calculations from SPSS software

* GOP - Gross Operating Profitability, CCC - Cash Conversion Cycle, LNS - Natural Logarithm of Sales, DR - Debt Ratio.

Significant interconnection can be proved if only GOP is expressed with the explanatory variable CCC.

In the selected group of the trade sector determination coefficients were acquired only in relation to $\mathrm{CCC}$ (Table 10).

TABLE 11.

Regression models for gross profitability forecasting according to various explanatory variables in the sphere of services

\begin{tabular}{|l|c|c|}
\hline \multicolumn{1}{|c|}{ Regression equation } & $\mathrm{R}$ & $\mathrm{R}^{2}$ \\
\hline $\mathrm{GOP}=-122.588-0.188 * \mathrm{CCC}-$ & 0.811 & 0.657 \\
$439.68 * \mathrm{DR}+15.579 \mathrm{Lns}$ & & \\
\hline
\end{tabular}

Source: author's data calculations from SPSS software
* GOP - Gross Operating Profitability, CCC - Cash Conversion Cycle, LNS - Natural Logarithm of Sales, DR - Debt Ratio.

The regression model for the sphere of services was developed expressing GOP with:

- CCC of $66 \%$, related to DR and LnS (Table 11).

The credibility of the acquired regression equations is sufficient to be used for forecasting profitability (GOP) at enterprises working in the sphere of services, managing the cash asset cycle influenced by all other indicators of management of current assets.

As a result of the empirical research the author worked out mathematical models with a high credibility for forecasting gross operating profitability using indicators, which characterise management of current assets at companies working in the sphere of production, trade and services. Realising purposeful policy of management of some types of current assets, managers of various enterprises can influence indicators of the turnover of current assets. Regular analysis and planning of these indicators, using the developed regression equations can facilitate achieving the enterprise's target, i.e. the desired level of profitability.

The author has proved the hypothesis that was brought forward in the beginning of the research enterprise managers can forecast and influence profitability of economic activity using management of elements of current assets.

\section{CONCLUSION}

Pearson's correlation analysis results show that between aspects of the management of various elements of current assets there is a close connection. As a result of the correlation analysis, the author proved that at enterprises in Latvia there is significant correlation between profitability and indicators characterising current asset management. The correlation analysis proved that there are differences between the spheres. The acquired analysis results about enterprises in Latvia differ from the studies done at companies in other countries, but it can be explained and characterises specific features of the management of current assets realised at enterprises in Latvia.

In scientific research, much attention is paid to the analysis of financial indicators within the aspect of management of current assets and diagnosing the financial situation of the enterprise. Managers more often perceive analysis results as a fact and wish to improve each separate indicator without their complex evaluation. Doing the regression analysis the author developed possible forecasting models allowing of predicting enterprise's activity profitability using indicators of management of current assets. 
All acquired regression coefficients are significant. Developed regression equations can be used for forecasting gross profit cost-efficiency and in decision making in relation to management of current assets, or, when implementing current asset management, gross activity profitability can be forecasted. The author offers more exact regression models divided into spheres of production, trade and services, which also ensures higher forecasting significance.

\section{REFERENCES}

[1] Arbidāne I., Ignatjeva S. The Relationship between Working Capital Management and Profitability: a Latvian Case. Research papers "Global Review of Accounting and Finance" Vol 4, No 1,2013. pp. 148-158

[2] Arbidāne I.,Mietule I., Silineviča I. Latgales regiona sociāli ekonomisko procesu izpēte. Rēzeknes Augstskola 2014. pp.221-227

[3] Deloof, M. Does Working Capital Management Affect Profitability of Belgian Firms. Journal of Business Finance \& Accounting, Vol. 30 (3), 2003, pp. 573-587.

[4] Dong, H.P. and Su, J. The Relationship between Working Capital Management and Profitability: A Vietnam Case. International Research Journal of Finance and Economics, Vol. 49, 2010, pp. 59-67.

[5] Enqvist J., Graham M., Nikkinen J. The Impact of Working Capital Management on Firm Profitability in Different Business Cycles: Evidence from Finland [tiešsaiste] (2011). Available at:http://ssrn.com/abstract $=1794802$

[6] Garcia-Tereul, P.J. and Martinez-Solano, P. Effects of Working Capital on SME Profitability. International Journal of Managerial Finance, Vol. 3 (2), 2007, pp. $164-177$.

[7] Gill, A., Biger, N., Mathur, N. The Relationship between Working Capital Management and Profitability: Evidence from the United States. Business and Economics Journal, Vol. 2010, pp. 1-9.

[8] Karaduman H.A., Halil E., Arzo O. Effects of Working Capital Management on Profitability: The Case for Selected Companies in the Istanbul Stock Exchange (2005-2008). International Journal of Economics and Finance Studies, Vol. 2 (2), 2010, pp. 47-54.

[9] Lazaridis I, Tryfonidis D, Relationship between working capital management and profitability of listed companies in the Athens stock exchange. Journal of Financial Management and Analysis, 19: pp. 2006, 26-25.

[10] Mathuva, D.M. The Influence of Working Capital Management Components on Corporate Profitability: A survey on Kenyan Listed Firms, Research Journal of Business Management, Vol. 4 (1), 2009, pp. 1-11.

[11] Nazir, M.S., Afza, T. Impact of Aggressive Working Capital Management Policy on Firms' Profitability. The IUP Journal of Applied Finance, Vol. 15 (8), pp. 2009, 19-30.

[12] Nobanee H. and Alhaijaar M. A Note on Working Capital Management and Corporate Profitability of Japanese Firms. Available at SSRN: http://ssrn.com/abstract=1433243. 2009.

[13] Padachi, K. Trends in Working Capital Management and its Impact on Firm "s Performance: An Analysis of Mauritian Small Manufacturing Firms. International Review of Business Research, Vol. 2 (2), 2006, pp. 45-58.

[14]Padachi, K. Trends in Working Capital Management and its Impact on Firm "s Performance: An Analysis of Mauritian Small Manufacturing Firms. International Review of Business Research, Vol. 2 (2), 2006, pp. 45-58.

[15] Raheman, A., Nasr, M. Working Capital Management And Profitability - Case Of Pakistani Firms. International Review of Business Research Papers, Vol. 3 (1), 2007, pp. 279-300.

[16] Raheman, A., Afza, T., Qayyum, A., Bodla, M.A. Working Capital Management and Corporate Performance of Manufacturing Sector in Pakistan. International Research Journal of Finance and Economics, Vol. 47, 2010, pp.151-163.

[17] Sharma, A.K. and Kumar, S. Effect of Working Capital Management on Firm Profitability: Empirical Evidence from India. Global Business Review, Vol. 12 (1), 2011, pp. 159-173.

[18]Shin, H.H., Soenen, L. Efficiency of working capital management and corporate profitability. Financial Practice and Education, 8(2), 1998, pp. 37-45. 